\title{
Automated Counting of Meloidogyne javanica Galls in Vegetable Roots
}

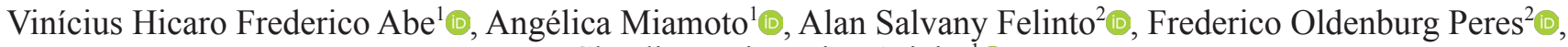 \\ Cláudia Regina Dias-Arieira ${ }^{1}$
} ${ }^{1}$ State University of Maringá, Post-Graduate in Agronomy, Avenida Colombo, n. 5790 - Bloco J45, 2 Piso, 87020-900, Maringá, Paraná, Brazil,
${ }^{2}$ State University of Londrina, Computer Department, Av. Colombo, 5790 - Jd. Universitário, Clobo J35, sala 02, CEP 87020-900, Maringá,
Paraná, Brasil.

Autor correspondente: Angélica Miamoto (angelicamiamoto@gmail.com)

Data de chegada: 23/03/2018. Aceito para publicação em: 08/02/2019.

$10.1590 / 0100-5405 / 193307$

\section{ABSTRACT}

Abe, V.H.F.; Miamoto, A.; Felinto, A.S.; Peres, F.O.; Dias-Arieira, C.R. Automated Counting of Meloidogyne javanica Galls in Vegetable Roots. Summa Phytopathologica, v.45, n.4, p.381-386, 2019.

Root-knot nematodes, genus Meloidogyne spp., are among the most destructive parasites of cultivated plants. The characteristic symptom of this disease is gall formation in the root system. Genetic resistance is one of the most efficient and economic methods of minimal environmental impact to control this endoparasite, and gall index has been used to select resistant varieties. However, this method is based on visual assessment of galls and is therefore a time-consuming and error-prone technique. Thus, this study aims to develop an automated computational method for Meloidogyne javanica gall counting. The proposed method was composed of five steps: visual counting of galls, image acquisition by a scanner, optimization of parameters based on the image group and image counting. Lettuce root showed the best results, with $1 \%$ mean relative error, while tomato root had the worst result, showing $32 \%$ mean relative error. The mean relative error for all tested roots was $13 \%$.

Keywords:Nematodes, Circular Correlation, Computer Vision, Genetic Algorithm

\section{RESUMO}

Abe, V.H.F.; Miamoto, A.; Felinto, A.S.; Peres, F.O.; Dias-Arieira, C.R. Contagem automatizada de galhas de Meloidogyne javanica em raízes vegetais. Summa Phytopathologica, v.45, n.4, p.381-386, 2019.

Os nematoides-das-galhas, gênero Meloidogyne spp., estão entre os parasitas mais destrutivos das plantas cultivadas. O sintoma mais característico da doença é o surgimento de galhas no sistema radicular. O uso da resistência genética é um dos mais eficientes, econômicos e menos impactantes do ponto de vista ambiental no controle desse endoparasita, sendo o índice de galhas uma das metodologias utilizadas para seleção de variedades resistentes. No entanto, é um método baseado na avaliação visual de galhas e, portanto, é uma técnica que exige tempo e é passiva de erros. Assim, este trabalho tem como objetivo desenvolver um método computacional automatizado para contar as gralhas de Meloidogyne javanica. O método proposto foi composto de cinco etapas: uma contagem humana visual de galhas, a aquisição de imagens de um scanner, otimização de parâmetros com base no conjunto de imagens e, finalmente, contagem das imagens. A raiz da alface produziu os melhores resultados, com $1 \%$ de erro relativo médio e a raiz do tomate o pior, com erro relativo médio de $32 \%$. O erro relativo médio para todas as raízes testadas foi de $13 \%$.

Palavras-chave: Nematoides, Correlação Circular, Visão Computacional, Algoritimo Genético

Every year, different Meloidogyne species have their number of galls and nematode eggs annually evaluated in the search for new control methods. Gall counting is generally expressed as total number of galls or gall index. In the literature, this type of evaluation has used several indexes such as those reported by Charchar et al. (3), Di Vito et al. (4), Hartman and Sasser (9), Sasser et al. (21) and Taylor and Sasser (23); the latter is one of the most used indexes worldwide.

Gall counting consists in observing the roots through magnifying glasses or the naked eye and directly quantifying the existing galls. This is a time-consuming method subject to error, which varies depending on the observer's experience. Its limitations are the impossibility of storing the roots for long periods, since they decompose rapidly, and the evaluation itself, which is destructive to the roots.

Thus, development of methods that are more rapid, less prone to error and that allow data or image storage for further study will greatly assist in nematode research. As an example, Lu et al. (15) adopted fluorescent imaging technology which increased the counting efficiency and accuracy for female Heteroderaglycines Ichinohe.

Considering phytopathology, for several years, informatization systems have constituted important tools for disease diagnosis (2, 14, 24).

Different techniques have been proposed for different areas of agriculture, including circle Hough transform and Euclidean distance measurement for castor bean counting, and skeletonization, routinely used for root distribution analysis in the fields, adopting the software available in the national market, such as SIARCS (Integrated System for Root and Soil Cover Analysis) and SAPPHIRE (Analysis System of Fibers and Roots) (11).

Scanners like ADC BioScientific AM $300^{\circledR}$ and Sigmascan ${ }^{\circledR}$ have been applied to various software for the measurement of several parameters; the first one is an image analysis program that uses color to determine the amount of necrotic or injured tissue (12) or the nutritional deficiency of leaves, among other variables (22), while the second one is a portable leaf area meter composed of a clipboard, a scanner 
and a computer, which measures the width, length, perimeter and area affected by the disease (16).

Some computer systems have been used in nematology for behavioral and quantification studies, including the digital image analysis system to study physical characteristics and detect differences between populations of Bursaphelenchus xylophilus (Steiner and Buhrer) Nickel (18). Skeleton-based analysis presented $83.7 \%$ accuracy for automatic detection of Caenorhabditis elegans Maupas in overlapped or isolated populations (19), while the "correlated random walk model in two dimensions" was adopted to study the nematode Phasmarhabditis hermaphrodita Schneider (8).

Although the root-knot nematode is the most important plantparasitic nematode in agriculture, there is a lack of advanced techniques for studies of pathosystems involving the different Meloidogyne species and their hosts. Thus, the objective of this study was to develop a gall counting software for Meloidogyne spp. on vegetables, comparing its efficiency with that of the traditional method of visual evaluation.

\section{MATERIAL AND METHODS}

\section{Visual Evaluation of Galls}

The experiment was conducted from March to June 2013, in a greenhouse at the State University of Londrina (UEL), Londrina-PR, Brazil, the coordinates of which are latitude $23^{\circ} 32^{\prime} 90^{\prime \prime} \mathrm{S}$ and longitude $51^{\circ} 20^{\prime} 4517^{\prime}$ 'W, with average elevation of 587 meters. A mixture of soil and sand was used at 2:1 ratio, which was sterilized in autoclave for 2 hours at $120^{\circ} \mathrm{C}$; then, $5 \mathrm{~L}$ pots were arranged in a completely randomized design (DIC), including ten replicates and three different plant species.

Seedlings of tomato cv. Santa Clara, parsley cv. Lisa and lettuce cv. White Boston were sown in 128-cell expanded polystyrene trays filled with sterile commercial substrate. Thirty days after sowing, the seedlings were transplanted to $5 \mathrm{~L}$ pots and, after another five-day period, 5,000 eggs and second-stage juveniles (J2) of M. javanica were inoculated in four equidistant holes located $2-3 \mathrm{~cm}$ apart from each other in the plant stem and 2-3 cm deep.

The inoculum was obtained from a pure population and multiplied in tomato cv. Santa Clara in a greenhouse. Nematode extraction was performed according to the method proposed by Hussey and Barker (10), adapted by Boneti and Ferraz (1). The inoculum was quantified

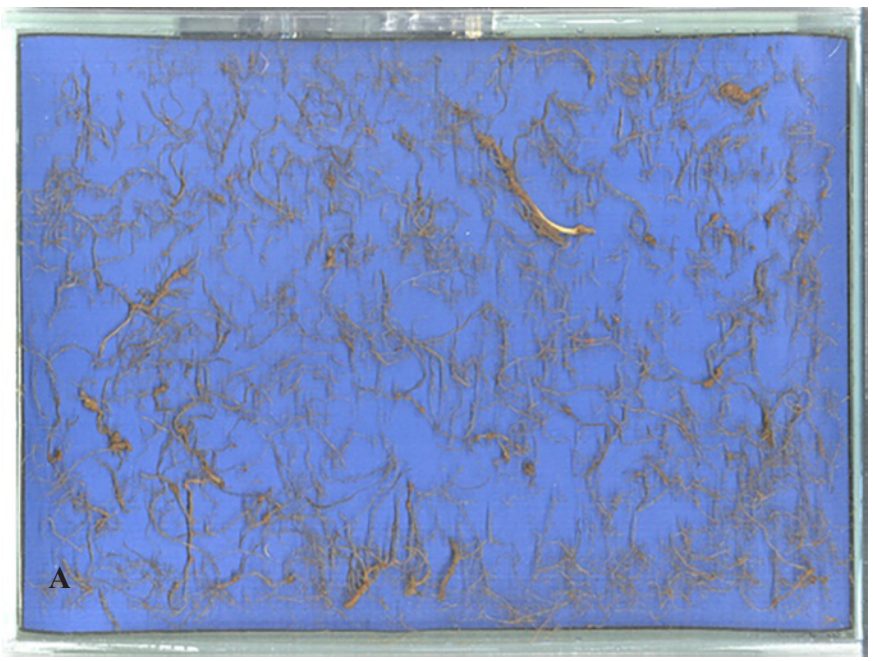

Figure 1. Image acquisition setup (a). Example of scanned image (b). by using nematode count blades (Peter's Chamber) under an optical microscope.

After 60 days, the aerial part was cut and the root system was carefully washed and packed in previously identified plastic bags. In the lab, fresh root mass was determined in a semi-analytical scale. Then, the galls were visually counted and evaluated by four different specialists, and the counting time was recorded for subsequent comparison.

\section{Image Acquisition}

The same roots used for gall counting were subjected to image acquisition. A customized glass box $(29.7 \mathrm{~cm} \mathrm{x} 21.5 \mathrm{~cm} \times 4.0 \mathrm{~cm})$ was made to fit the scanning area of the scanner, as shown in Figure 1a. The scanner model was HP Scanjet 2200c. A deep navy blue polypropylene background was used to improve segmentation. The used program was VueScan, version 9.2.04 for scanning, configured to obtain images at 300 dpi resolution.

The glass box was positioned on the scanner and $500 \mathrm{~mL}$ water was poured into the box. For better distribution and to avoid overlapping, each root was subdivided according to its volume up to four samples, using forceps and a scalpel. Then, the blue background was carefully positioned beneath the edge of the water surface in order to avoid air bubble formation and the scanner lid was put on the glass box. The image was obtained and the time needed for scanning was recorded. The scanner setup and an example of the obtained image can be seen in Figures 1a and 1b, respectively.

\section{Computational Model}

The gall counting algorithm was developed based on known image processing and artificial intelligence techniques, such as segmentation methods and a genetic algorithm. The method consists of two main phases: optimization and execution.

A genetic algorithm was used to optimize the existing parameters within the execution algorithm, using a base of images counted by novices for training and comparison in order to get as close as possible to the values found by experts.

\section{Nematode Counting Algorithm}

The counting algorithm is adopted to obtain the quantity of circular bulges in the image. As roots varied in volume, some of them needed to be divided into multiple images, in order to avoid overlapping galls.

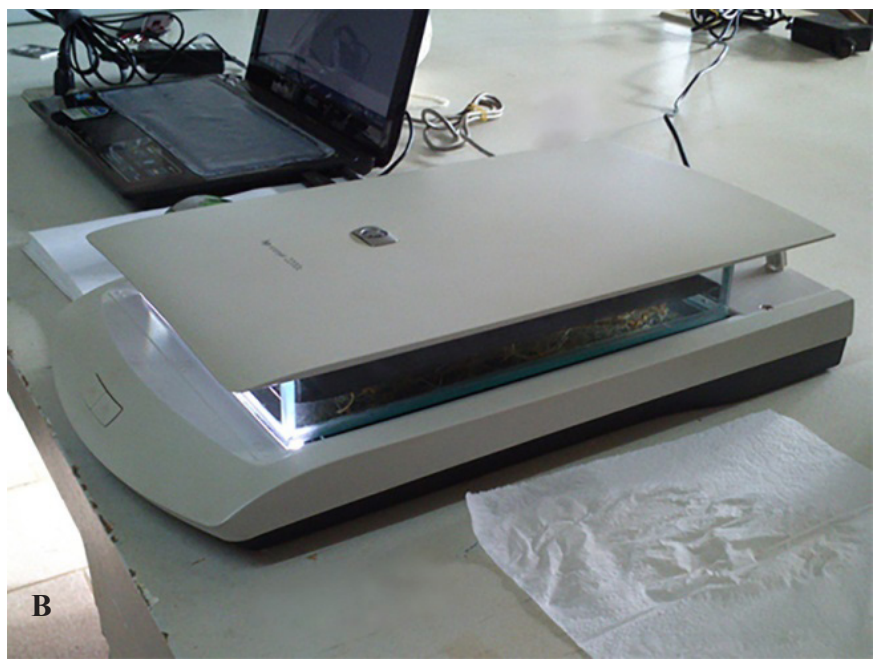


Therefore, the algorithm had to be run for each image that composed it, which were summed up to obtain the total galls present in the roots.

The counting process followed a sequence of steps. First, a threshold was used to separate the background from the roots, and a fixed size cut was adopted to eliminate the borders of the scanner; then, a median filter was applied to remove image noise.

According to the adopted process, for each image pixel in the root area, a circle was spread across the image centered on the pixel in question in order to find the biggest circle that could fit inside the root area previously determined in the first step. These values for each pixel were then stored in a matrix of dimensions equal to those of the original image.

Subsequently, the radius values were compared among the neighboring pixels, counting the number of neighbors that had values lower than that of the pixel itself, and storing a new matrix with dimensions equal to those of the image. This step was necessary to prevent the counting of multiple peaks within a single gall, which would generate a large amount of false positives. Then, the peaks inside the neighborhood matrix were counted. The obtained number was considered the number of galls found on the image.

This sequence was performed for each image that composed one same root, and the values were summed up to obtain the total count for the root. When there were no more images related to the root in question, the absolute value of the difference between the total points and the expected value was then calculated and divided by the expected value, yielding the relative error.

The expected value used by the model was obtained from the average of the values previously counted by the four specialists. The relative error was subsequently used for the evaluation of each of the individuals in the genetic algorithm.

\section{Parameter Optimization}

A genetic algorithm was used to optimize the parameters of the counting algorithm. As defined by Mitchell (17), a genetic algorithm is a heuristic search that simulates a natural selection process. It is generally used for optimization and search problems. The algorithm is composed of two main steps: the testing and evaluation of an existing population and the introduction of a new generation from the previous one; both steps are described below.

Each population is composed of 10 individuals with 7 genes each.
These genes correspond to 7 variables required for the previously described method. Thus, an individual is defined by a set of parameters required in the gall counting algorithm.

The objective of the genetic algorithm was to optimize the parameters for a specific set of images, allowing the count of any image showing similar characteristics with minimal accuracy loss, provided that the image contains the same type of root (tomato, for example) and similar acquisition methods.

Every algorithm generation leads to the generation of a new population which has to be validated. The diagram of the validation process of a population can be observed in Figure 2a. Initially, an individual containing a set of parameters, as previously described, is selected from the population. The counting algorithm is run for each of the images present in the test set, using the defined parameters contained in the individual under evaluation. The mean relative error is calculated for the individual in question and used as the fitness value in the genetic algorithm. The next individual is then selected and the same process is repeated until the entire population has a fitness value.

In general, the genetic algorithm works as indicated in the diagram of Figure 2b. An initial population is randomly generated, which is composed of 10 individuals with the random gene values within the limits allowed by each variable. Then, the process previously described for the validation of the population is performed. The two individuals with the best fitness values are then selected as the parents of the next generation.

The selected parents originate a new population, and each individual of it is the result of a random combination of genes from their parents. This new generation then passes through a mutation phase, in which each gene of each individual of the current population has $5 \%$ chance of being assigned with a new random value, losing the original inheritance from the parents. The latter are kept intact and added as members of the next generation to prevent the regression of the solution.

After the evaluation of each generation, the stopping conditions were checked. Generally, the algorithm terminates when the execution reaches a predetermined minimum error set by the user but, in theory, it allows the algorithm to run infinitely if the minimum error is not reached. To prevent this problem, the algorithm can also stop when a given number of generations is achieved without any reduction in the solution error.

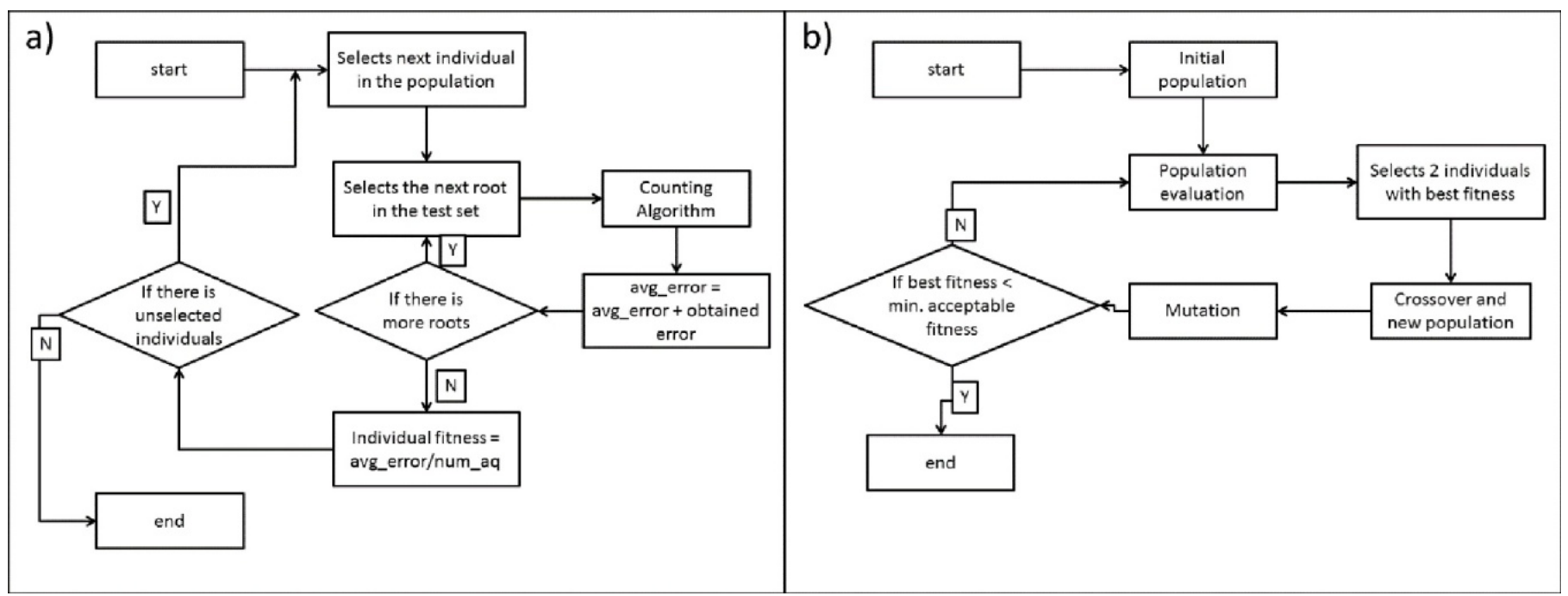

Figure 2. a) The evaluation algorithm. b) General view of the genetic algorithm. 


\section{RESULTS AND DISCUSSION}

The automatic counting method yielded favorable results; the smallest relative error was $1 \%$ for lettuce root, while the greatest relative error was $32 \%$ for tomato root, and the mean relative error was $13 \%$ (Table 1). Dunn et al. (5) used digital images of the grape vine Cabernet Sauvignon, analyzed by the program "Easy Access" 6.3 version, to automatically count the fruits and estimate the productivity before harvest; they obtained $85 \%$ correlation with the weight of fruits.

Wijekoon et al. (25) evaluated the severity of anthracnose in $N$. benthamiana. The leaves were inoculated with different amounts of $C$. destructivum and after 96 hours the number of visible points counted by the authors were compared with the disease severity measured by the image analysis software "Scion"; the obtained correlation was $74 \%$ and the probability, $\mathrm{P}=0.0001$.

The automated method showed absolute errors of 28, 47 and 169, and standard deviations of 48.68, 102.50 and 220.9 for lettuce, parsley and tomatoes, respectively, compared to visual counting by specialists. The absolute errors obtained by the automated method were close to and below the standard deviations obtained by manual counting (Tables 1 and 2), indicating that the automated method was less sensitive to variation than the manual counting. The results of both methods had better expression for lettuce, followed by parsley and tomatoes. As the standard deviation increased, both the absolute and relative errors increased, showing that the automated counting accuracy for certain roots was a reflection of the greater difficulty in identifying the galls, even for visual counting by specialists.

Another result is the time spent for manual counting, an average of 19 minutes per root (Table 3 ). The automated method developed in this study takes an average time of 4 seconds per root, when performed by a computer with medium settings, plus the time necessary for image acquisition by the scanner, an average of 23 seconds at 300 dpi resolution, besides the settling time of the roots in the glass box, on average 02:40 minutes for $30 \mathrm{~g}$ root (Table 4), resulting in 03:07 minutes, which is an extremely high gain of average 16 minutes spent on the task. In this study, the average fresh root mass was $32.62,43.34$ and 30.87 for lettuce, parsley and tomato, respectively (Table 5). The advantage of using the scanner is that such a method stores an in situ

Table 1. Number of galls counted by the evaluators (AVL) and by automated counting method (AUTO); absolute error (EABS) and relative error (EREL) obtained by comparing both methods, and average values (AVG) for roots of lettuce, tomato and parsley, inoculated with 5000 eggs of Meloidogyne javanica.

\begin{tabular}{|c|c|c|c|c|c|c|c|c|c|c|c|c|}
\hline \multirow[t]{2}{*}{ Root } & \multicolumn{4}{|c|}{ Lettuce } & \multicolumn{4}{|c|}{ Parsley } & \multicolumn{4}{|c|}{ Tomato } \\
\hline & AVL & AUTO & EABS & EREL & AVL & AUTO & EABS & EREL & AVL & AUTO & EABS & EREL \\
\hline 01 & 574 & 507 & 66 & 0.12 & 547 & 575 & 29 & 0.05 & 1216 & 873 & 343 & 0.28 \\
\hline & 403 & & & & & & & & & & & \\
\hline 03 & 464 & 489 & 25 & 0.05 & 367 & 365 & 02 & 0.01 & 886 & 897 & 11 & 0.01 \\
\hline 05 & 116 & 97 & 19 & 0.16 & 389 & 370 & 19 & 0.05 & 710 & 880 & 170 & 0.24 \\
\hline 06 & 458 & 461 & 03 & 0.01 & 205 & 240 & 35 & 0.17 & 1334 & 906 & 428 & 0.32 \\
\hline 07 & 332 & 312 & 20 & 0.06 & 265 & 229 & 36 & 0.14 & 555 & 481 & 74 & 0.13 \\
\hline 08 & 581 & 605 & 24 & 0.04 & 452 & 369 & 83 & 0.18 & 914 & 810 & 104 & 0.11 \\
\hline
\end{tabular}

Table 2.Number of galls counted by four evaluators (EV1 to EV4), comparing the standard deviation (SDV) and the average standard deviation $(\mathrm{AVG})$ for roots of lettuce, tomato and parsley, inoculated with 5000 eggs of Meloidogyne javanica.

\begin{tabular}{|c|c|c|c|c|c|c|c|c|c|c|c|c|c|c|c|}
\hline \multirow[t]{2}{*}{ Root } & \multicolumn{5}{|c|}{ Lettuce } & \multicolumn{5}{|c|}{ Parsley } & \multicolumn{5}{|c|}{ Tomato } \\
\hline & EV1 & EV2 & EV3 & EV4 & SDV & EV1 & EV2 & EV3 & EV4 & SDV & EV1 & EV2 & EV3 & EV4 & SDV \\
\hline 1 & 651 & 545 & 564 & 533 & 53.38 & 609 & 723 & 468 & 386 & 149.4 & 1249 & 1262 & 1025 & 1326 & 131.4 \\
\hline 2 & 420 & 436 & 424 & 333 & 47.32 & 427 & 485 & 306 & 318 & 86.6 & 562 & 550 & 538 & 745 & 98.0 \\
\hline 3 & 512 & 404 & 565 & 375 & 89.49 & 370 & 475 & 407 & 216 & 109.7 & 822 & 905 & 1166 & 651 & 214.5 \\
\hline 4 & 452 & 360 & 354 & 306 & 60.99 & 352 & 386 & 347 & 347 & 18.8 & 877 & 1603 & 936 & 1067 & 331.2 \\
\hline 5 & 112 & 132 & 117 & 102 & 12.50 & 313 & 384 & 297 & 460 & 60.3 & 923 & 886 & 677 & 355 & 260.4 \\
\hline 6 & 530 & 418 & 454 & 430 & 50.27 & 205 & 87 & 207 & 320 & 95.1 & 1282 & 1490 & 1629 & 934 & 302.2 \\
\hline 7 & 434 & 289 & 338 & 266 & 74.48 & 151 & 162 & 150 & 597 & 221.4 & 274 & 693 & 494 & 760 & 218.9 \\
\hline 8 & 650 & 504 & 551 & 619 & 65.91 & 388 & 455 & 402 & 562 & 79.0 & 854 & 1154 & 911 & 658 & 210.3 \\
\hline AVG & & & & & 49 & & & & & 102 & & & & & 221 \\
\hline
\end{tabular}


Table 3.Average time, in minutes, spent on manual quantification of galls by all evaluators for lettuce, parsley and tomato inoculated with 5000 eggs of Meloidogyne javanica.

\begin{tabular}{cccccccccccc}
\hline & \multicolumn{1}{c}{ Average time (minutes) } \\
\hline Root & 1 & 2 & 3 & 4 & 5 & 6 & 7 & 8 & Average overall \\
Lettuce & 19 & 16 & 15 & 16 & 12 & 19 & 18 & 21 & 17 \\
Parsley & 24 & 18 & 17 & 19 & 18 & 10 & 11 & 18 & 17 \\
Tomato & 27 & 15 & 20 & 26 & 17 & 32 & 16 & 21 & 22 \\
\hline
\end{tabular}

Table 4. Average settling time for 30 grams root in glass box.

\begin{tabular}{ccccccc}
\hline \multicolumn{7}{c}{ Average time (minutes) } \\
\hline Repetition & 1 & 2 & 3 & 4 & Average overall \\
\hline Time & $02: 46$ & $02: 29$ & $02: 32$ & $02: 54$ & $02: 36$ & $02: 40$ \\
\hline
\end{tabular}

Table 5. Fresh weight of roots of lettuce, parsley and tomato after 60 days of cultivation in pots infested with 5000 eggs of Meloidogyne javanica.

\begin{tabular}{lccccccccc}
\hline \multicolumn{10}{c}{ Fresh weight of roots (g) } \\
\hline Root & $\mathbf{1}$ & $\mathbf{2}$ & $\mathbf{3}$ & $\mathbf{4}$ & $\mathbf{5}$ & $\mathbf{6}$ & $\mathbf{7}$ & $\mathbf{8}$ & Average overall \\
\hline Lettuce & 29.59 & 23.25 & 24.41 & 55.45 & 21.74 & 34.75 & 26.64 & 45.11 & 32.62 \\
Parsley & 58.31 & 48.69 & 27.45 & 53.21 & 50.07 & 36.82 & 34.59 & 37.61 & 43.34 \\
Tomato & 38.68 & 24.22 & 24.57 & 40.18 & 26.07 & 37.91 & 21.61 & 33.68 & 30.87 \\
\hline
\end{tabular}

collection of permanent images that can be reviewed subsequently (7), in addition to its low cost. Digital images have been used to count colony-forming units (6), measure the anthracnose lesion area in cucumber (13), quantify fungal infection in plant leaves (25), and constrict and validate a diagrammatic scale for assessment of Phoma spot severity in coffee trees (20).

The time required for training before this algorithm could be used was approximately 4 hours to reach the optimal parameters. This period is required for each database, but once training is completed, the algorithm works with any image similar to those used in training in terms of background color, approximate color of the roots, cutting edges, photo shooting distance and illumination. If these conditions are not met, the algorithm can still perform the count, but optimal results are not guaranteed.

The automated method proved to be more accurate than assessment by specialists; there was less divergence in relation to the standard deviation for the counting by specialists, as well as a reduced counting time and financial cost.

The obtained results represent a great contribution to the currently available state of the art equipment. An unprecedented model was presented for the computer-automated counting of galls on roots, along with a model for optimizing the parameters of this method, enabling the adaptation and implementation of the proposed technique to different databases.

The presented method yielded average absolute errors of 28,47 and 169 , compared with the average standard deviation of $48.68,102.50$ and 220.90 in the count done by the evaluators for lettuce, parsley and tomatoes, respectively. The time per root was also greatly reduced.

For a future study, a more effective optimization method will be developed to allow a shorter training time, which is probably the major downside of the present method. Other methods may also be proposed for the identification and counting of galls in an attempt to reduce the error and consequently increase the precision of the procedure.

\section{REFERENCES}

1. Boneti, J.I.S.; Ferraz, S. Modificação do método de Hussey e Barker para extração de ovos de Meloidogyneexigua de raízes de cafeeiro. Fitopatologia Brasileira, Brasília, DF, v.6, n.1, p.553, 1981.

2. Boyd, D.W.; Sun, M.K. Prototyping an expert system for diagnosis of potato diseases. Computers and Electronics in Agriculture, Medford, v.10, n.3, p.259-267, 1994.DOI:10.1016/0168-1699(94)90045-0

3. Charchar, J.M.; Gonzaga, V.; Giordano, L.B.; Boiteux, L.S.; Reis, N.V.B.; Aragão, F.A.S. Reações de cultivares de tomate à infecção por população mista de Meloidogyneincognitaraça 1 e M. javanicaem estufa plástica e campo. Nematologia Brasileira, Brasília, DF, v.27, n.1, p.49-54, 2003.

4. Di Vito, M.; Lamberti, F.; Carella, A. La resistenzadel pomodoro neiconfronti dei nematodigalligeni: prospettive e possibilità. Rivistadi Agronomia, Bolonga, v.13, n.1, p.313-322, 1979.

5. Dunn, G.M.; Martin, S.R. Yield prediction from digital image analysis: A technique with potential for vineyard assessments prior to harvest. Australian Journal of Grape and Wine Research, Sydney, v.10, n.3, p.196-198, 2004.DOI:10.1111/j.1755-0238.2004.tb00022.x

6. Geissmann, Q. Open CFU, a new free and open-source software to count cell colonies and other circular objects. PloS One, San Francisco, v.8, n.2, p.54072, 2013.DOI:10.1371/journal.pone.0054072

7. Han, L.; Dutilleul, P.; Prasher, S.O.; Beaulieu, C.; Smith, D.L. Assessment of common scab-inducing pathogen effects on potato underground organs via computed tomography scanning. Phytopathology, Athens, v.98, n.10, p.1118-1125, 2008.DOI:10.1094/PHYTO-98-10-1118

8. Hapca, S.; Crawford, J.; MacMillan, K.; Wilson, M.J.; Young, I.M. Modelling nematode movement using time-fractional dynamics. Journal of Theoretical Biology, Medford, v.248, n.1, p.212-224, 2007.DOI:10.1016/j. jtbi.2007.05.002

9. Hartman, K.M.; Sasser, J.N. Identification of Meloidogyne species on the basis of differential host test and perineal-pattern morphology. In: Barker, 
K.R; Carter, C.C.; Sasser, J.N. Advanced Treatise on Meloidogyne. 2nd ed. North Carolina: North Carolina State University, 1985. p.69-77.

10. Hussey, R.S.; Barker, K.R. A comparison of methods collecting inocula of Meloidogyne spp. including a new technique. Plant Disease Reporter, St. Paul, v.57, n.5, p.1025-1028, 1973.

11. Jorge, L.A.C.; Rodrigues, A.F.O. Safira: sistema de análise de fibra e raiz. São Carlos: Embrapa Instrumentação Agrícola, 2008. 20p.(Boletim de Pesquisa e Desenvolvimento).

12. Karcher, D.E.; Richardson, M.D. Batch analysis of digital images to evaluate turfgrass characteristics. Crop Science, Rhein, v.45, n.1, p.1536-1539, 2005. DOI:10.2135/cropsci2004.0562

13. Kwack, M.S.; Kim, E.N.; Lee, H.; Kim, J.W.; Chun, S.C.; Kim, K.D. Digital image analysis to measure lesion area of cucumber anthracnose by Colletotrichum orbiculare. Journal of General Plant Pathology, St. Paul, v.71, n.1, p.418-421, 2005.DOI:10.1007/s10327-005-0233-0

14. Latin, R.X.; Miles, G.E.; Rettinger, J.C. Expert systems in plant pathology. Plant Disease, St. Paul, v.71, n.1, p.866-872, 1987.DOI:10.1109/ TLA.2016.7483534

15. Lu, H.; Tallman, J.; Hu, X.; Anderson, E.; Chamberlin, M.; Lu, G. An innovative method for counting females of soybean cyst nematode with fluorescence imaging technology. Journal of Nematology, Tallahassee, v.37, n.4, p.495-499, 2005

16. Lucena, T. Sistemas Enativos Afetivos em Arte e TecnoCiência: experiências vitais dos deslocamentos na cidade. 2013. 243f. Tese (Doutorado em Arte). Universidade de Brasília, Brasília-DF.

17. Mitchell, M. An introduction to genetic algorithms. Cambridge: MIT, 1996. $158 \mathrm{p}$
18. Peet, F.G.; Panesar, T.S.; Sahota, T.S.; Sutherland, J.R.A digital image analysis system for comparing groups of small nematodes. Journal of Nematology, Tallahassee,v.22, n.3, p.407-413, 1990.

19. Rizvandi, N.B.; Pizurica, A.; Rooms, P.; Philips, W. Skeleton analysis of population images for detection of isolated and overlapped nematode $C$. Elegans. In: European Signal Processing Conference, 16, 2008, Lausanne. Anais. Lausanne: EURASIP, 2008. p.25-29.

20. Salgado, M.; Pozza, E.A.; Lima, L.M.D.; Pereira, R.T.; Pfenning, L.H. Escala diagramática para avaliação da severidade da mancha de Phoma do cafeeiro. Tropical PlantPathology, Brasília, DF, v.3, n.4, p.422-427, 2009. DOI: $10.1590 /$ S1982-56762009000600010

21. Sasser, J.N.; Carter, C.C.; Hartman, K.M. Standardization of host suitability studies and reporting of resistance to root-knot nematode. Taleigh: North Carolina State University, 1984. 7p.

22. Systat Software Inc. Sigma SCAN Automated Imag e Analysis. San Jose, 2015.Avaliable on: $<$ http://www.sigmaplot.com/products/sigmascan/ scan-produses-whitepaper2.php>. Access in: 26 nov. 2017.

23. Taylor, A.L.; Sasser, J.N. Biology, identification and control of root-knot nematodes (Meloidogyne species). Raleigh: North Carolina State University, 1978. 111p.

24. Travis, J.W.; Latin, R.X. Development, implementation, and adoption of expert systems in plant pathology. Annual Review of Phytopathology, Palo Alto, v.29, n.1, p.343-360, 1991.DOI:10.1146/annurev. py.29.090191.002015

25. Wijekoon, C.P.; Goodwin, P.H.; Hsiang, T. Quantifying fungal infection of plant leaves by digital image analysis using Scion Image software. Journal of Microbiological Methods, St. Paul, v.74, n.2/3, p.94-101, 2008. DOI:10.1016/j.mimet.2008.03.008 